\title{
THE EFFECT OF TWEEN 80, PALM KERNEL OIL, AND ITS CONVERSION PRODUCT ON IN VITRO PENETRATION ENHANCEMENT OF INDOMETHACIN THROUGH RABBIT SKIN
}

\author{
ANAYANTI ARIANTO*, RIZKI AMELIA, HAKIM BANGUN \\ Department of Pharmaceutical Technology, Faculty of Pharmacy, Nanomedicine Center, University of Sumatera Utara, \\ Jalan Tri Dharma No. 5, Kampus USU, Medan, Indonesia. Email: anayantia@yahoo.com
}

Received: 21 March 2017, Revised and Accepted: 17 April 2017

\section{ABSTRACT}

Objective: Objective of the study was to evaluate the effect of Tween 80, palm kernel oil (PKO), and its conversion products (hydrolyzed and transesterificated products) on the in vitro rabbit skin penetration of indomethacin from hydrocarbon ointment base.

Materials and Methods: In vitro penetration of indomethacin through hairless rabbit skin from hydrocarbon ointment base (white petrolatum) was evaluated using a diffusion cell. The effects of Tween 80, PKO, and its conversion products at various concentrations were evaluated.

Results: The higher of the concentration of Tween 80 until 5\%, the higher of the indomethacin penetration. However, at the concentration above $5 \%$, the penetration was decreased with the increasing concentration of Tween 80 used. The amount of indomethacin penetrated increased with the increasing of the concentration of PKO and its conversion products used. Hydrolyzed product showed the higher indomethacin penetration enhancing effect than PKO. Transesterificated product showed the highest penetration enhancing effect. However, the combination of Tween 80 with transesterificated product showed lower penetration enhancing effect compared to transesterificated product only.

Conclusion: Tween 80 at low concentrations, PKO, and its conversion products could be used to enhance indomethacin penetration.

Keywords: Indomethacin, Penetration, Tween 80, Palm kernel oil, Palm kernel oil conversion products.

(C) 2017 The Authors. Published by Innovare Academic Sciences Pvt Ltd. This is an open access article under the CC BY license (http://creativecommons. org/licenses/by/4. 0/) DOI: http://dx.doi.org/10.22159/ajpcr.2017.v10i7.18608

\section{INTRODUCTION}

Stratum corneum is the outer layer of skin, which is the actual barrier to most topically administered drugs. It consists of lipid (5-15\%) including phospholipids, cholesterol sulfate and neutral lipid, protein (75-85\%) which is mainly keratin [1]. To overcome this skin barrier problem, the penetration enhancer is necessary to promote drug penetration. These penetration enhancers ideally diminish impermeability of the skin [2].

Indomethacin is a potent nonsteroidal anti-inflammatory drug that is widely used in the treatment of rheumatoid arthritis, osteoarthritis, ankylosing spondylitis, and acute gouty arthritis [3]. However, it can cause gastric irritation if it is delivered orally. Hence, a transdermal dosage form which is easier to administer, noninvasive, consistent serum drug levels, reduction of side effects and avoid first-pass metabolism is important to develop [4]. Indomethacin is suitable for this dosage form because it has low molecular weight and low polarity [5].

However, due to slow penetration of indomethacin across the skin, the various approaches taken to increase the penetration of indomethacin through the skin. It was reported that ester of indomethacin can be used to increase the penetration rate of indomethacin through the skin [6]. Several compounds such as lemongrass [7], azone [8], menthol [9], Tween 80 [10], combination of Tween 80 and palm kernel oil (PKO) [11], oleic acid [11-13], fatty acid esters [14], and phospholipids [15] have also been suggested to act as penetration enhancer.

Tween 80 is an ionic surfactant that usually used in pharmaceutical formulation [5]. The effect of Tween 80 on in vitro ascorbic acid penetration through rabbit skin has been investigated, and the study showed that Tween 80 at low concentration $(2.5 \%$ and $5 \%)$ could enhance the penetration of hydrophilic active ingredients such as ascorbic acid but at high concentration (10\%) decreased the penetration [11]. The author was interested in the evaluation of Tween 80 as enhancer for lipophilic active ingredients such as indomethacin to compare the results.

Nowadays, PKO and its conversion products (hydrolyzed and transesterificated products) have been used in the production of food, cosmetics, detergent [7] and biodiesel [8]. But as far as the author's concern, the use of PKO and its conversion products as enhancer in transdermal dosage form has not been widely used. The author was interested in the evaluation of PKO and its conversion products as enhancers on the penetration of indomethacin through rabbit skin.

The work described in this report was undertaken to study the effect of Tween 80, PKO and its conversion products on in vitro penetration enhancement of indomethacin through rabbit skin from hydrocarbon ointment base.

\section{MATERIALS AND METHODS}

\section{Materials}

Indomethacin (Wako Pure Chemical Industries, Japan), PKO (PT. Multimas Nabati Asahan, Indonesia), hydrolyzed PKO and transesterificated PKO (synthesized by Laboratory of Physical Pharmacy, Faculty of Pharmacy, University of Sumatera Utara), Tween 80, potassium dihydrogen phosphate, and sodium hydroxide (Merck, Germany), white petrolatum (PT. Brataco, Indonesia) were used in this study.

Preparation of absorption curve for indomethacin

An accurately weighed $25 \mathrm{mg}$ of indomethacin was dissolved in $\mathrm{pH} 7.4$ of phosphate buffer solution, and the volume was made up to $500 \mathrm{ml}$ to obtained $50 \mu \mathrm{g} / \mathrm{ml}$ of stock solution. Then, as much as $5 \mathrm{ml}$ of this stock solution was withdrawn and made up to $25 \mathrm{ml}$ with $\mathrm{pH} 7.4$ of phosphate buffer solution. The indomethacin solution was determined using ultraviolet (UV) spectrophotometer (UV-1800 Shimadzu UV Spectrophotometer) at a wavelength of $266.8 \mathrm{~nm}$. 
Preparation of calibration curve of indomethacin

Aliquot of $0.15,0.5,2,4,5,6,7,8$, and $9 \mathrm{ml}$ of stock solution were diluted to $25 \mathrm{ml}$ with pH 7.4 of phosphate buffer solution to produce $0.3,1,4$, $8,10,12,14,16$ and $18 \mu \mathrm{g} / \mathrm{ml}$ of indomethacin solution, respectively. The absorbance of these solutions was determined by using UV spectrophotometer at $266.8 \mathrm{~nm}$.

\section{Preparation of rabbit skin}

Rabbit skin was used to evaluate the percutaneous absorption of indomethacin. A male rabbit weighing $1.5-2 \mathrm{~kg}$ was housed in room temperature. It was allowed free access to food and water for a week [9]. The hair of abdominal area of the rabbit was carefully shaved off with hair clipper. This procedure was carried out a day before excising the skin to allow the skin to condition itself to the environment. The rabbit were sacrificed by ether inhalation and the hairless skin was excised with surgical scissors. The subcutaneous fat was removed carefully, rinsed with normal saline, wrapped in aluminum foil and storage at $-50^{\circ} \mathrm{C}$ until used [10]. Each skin specimen was cut into approximately 1 -inch squares. The specimen was thawed in a $37^{\circ} \mathrm{C}$ water bath for 4 minutes and then placed in the dish containing normal saline overnight to ensure complete hydration and the rabbit skin was ready for use [6].

\section{Preparation of formulations}

The weighed indomethacin was put into the mortar. Tween 80, PKO, hydrolyzed PKO or transesterificated PKO was added to the mortar if the formula consist it. Then, white petrolatum put into the mortar and triturated until homogenized. The composition of each formulation used is shown in Table 1.

\section{In vitro penetration studies}

The penetration of indomethacin across excised hairless rabbit skin was investigated using diffusion cell, consisted of a donor and receptor compartment. The volume was $10.8 \mathrm{ml}$ each and the effective area available for penetration was $1.29 \mathrm{~cm}^{2}(\mathrm{~d}=1.28 \mathrm{~cm})$. The skin was applied with $0.1 \mathrm{~g}$ of indomethacin ointment and mounted between the donor and receptor compartment where the stratum corneum side faced the donor compartment, and the dermal side faced the receptor compartment and in contact with $\mathrm{pH} 7.4$ of phosphate buffer solution. After securely clamping the diffusion cell assembly together, the receptor compartment was filled with $\mathrm{pH} 7.4$ of phosphate buffer solution equilibrated to $37^{\circ} \mathrm{C}$ which was stirred using a magnetic bar continuously.

At certain interval of time, $1 \mathrm{ml}$ sample was withdrawn from the receptor compartment and replaced immediately with an equal volume of fresh $\mathrm{pH} 7.4$ of phosphate buffer solution. The sample diluted with $\mathrm{pH} 7.4$ of phosphate buffer solution and determined spectrophotometrically at $266.8 \mathrm{~nm}$. Each set of experiments were carried out up to $9 \mathrm{hrs}$ and in triplicate.

\section{Statistical analysis}

All statistical analyses were performed using SPSS ${ }^{\circledast}$ Statistic 17. One-way ANOVA, followed by a post-test (Tukey's multiple comparison) were used when significant differences at $p<0.05$ were present.

\section{RESULTS AND DISCUSSION}

Effect of Tween 80 concentration on the in vitro indomethacin penetration through rabbit skin

The effect of Tween 80 concentration at low concentrations on the in vitro indomethacin penetration through rabbit skin is shown in Fig. 1. The results show that at concentration of $1 \%, 2.5 \%$ and $5 \%$, Tween 80 increase the penetration of indomethacin. The amount of indomethacin penetrated through rabbit skin to the medium in the receptor compartment was higher in the formula contained Tween 80 compared to formula without Tween 80 . The higher concentration of Tween 80 until 5\%, the significantly higher of the indomethacin penetration $(p<0.05)$. Fig. 2 shows the effect of Tween 80 concentration at high concentration of Tween $80(7.5 \%$ and $10 \%)$ on indomethacin

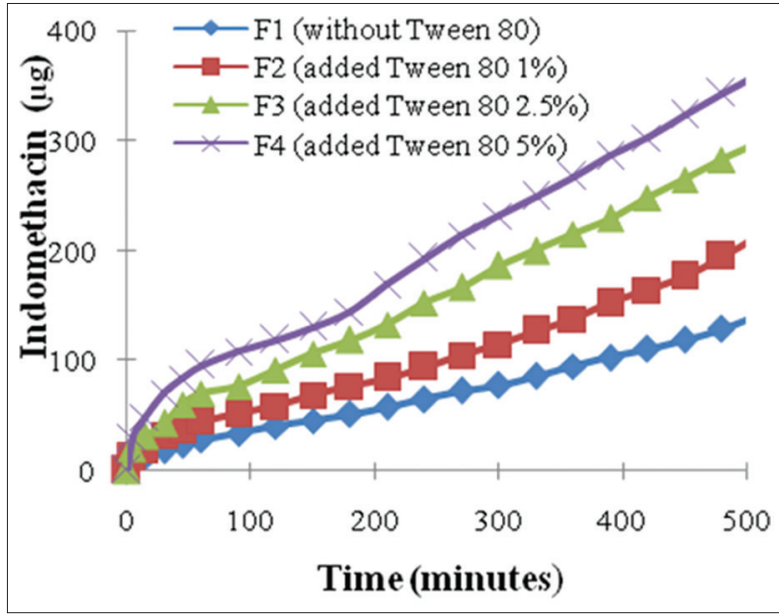

Fig. 1: Effect of Tween 80 at low concentration on the in vitro penetration of indomethacin in $\mathrm{pH}$ 7.4 of phosphate buffer solution at $37^{\circ} \mathrm{C}$

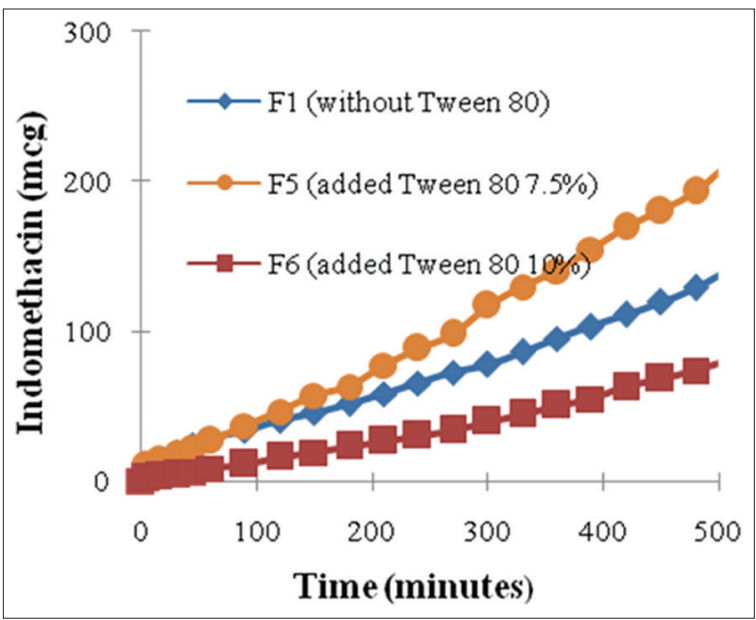

Fig. 2: Effect of Tween 80 at high concentration on the penetration of indomethacin in vitro in $\mathrm{pH} 7.4$ of phosphate buffer solution at $37^{\circ} \mathrm{C}$

penetration. When concentration of Tween 80 above 5\%, the indomethacin penetration decreased with the increasing of the Tween 80 concentration used and the reduction was significant statistically. Fig. 3 shows the effect of overall Tween 80 concentrations used on the indomethacin penetration at $270^{\text {th }}$ minute. This graphs show that there is a certain optimum concentration of Tween 80 to enhance the drug penetration.

The results indicate that there are several mechanisms of Tween 80 which lead to the increasing and decreasing of the penetration of indomethacin through rabbit skin. At low concentration $(1 \%, 2.5 \%$, and $5 \%)$, Tween 80 enhanced the penetration of indomethacin compared to formula without Tween 80. This enhancing effect is due to Tween 80 is a surfactant, where surfactant has potential to disrupt the skin barrier function by solubilizing the stratum corneum lipids. Moreover, surfactant can interact with keratin within the stratum corneum [5]. On the contrary, at concentration above 5\% $(7.5 \%$ and $10 \%)$, Tween 80 decreased the penetration of indomethacin. This reduction is also due to Tween 80 is a surfactant, where the surfactant can aggregate to form micelles [14]. So that, surfactant has potential to solubilize lipophilic ingredients [5] such as indomethacin. Finally, the indomethacin is trapped in the micelles so that could not pass through the skin because of the large size of the micelles. 
Effect of PKO concentration on the in vitro indomethacin penetration through rabbit skin

Fig. 4 shows the effect of PKO on the penetration of indomethacin in vitro. The amount of indomethacin penetrated increased with the increasing concentration of PKO used in the formulation. The amount of indomethacin penetrated through rabbit skin to the medium in the receptor compartment was higher in the formula contained PKO compared to formula without PKO.

The amount of penetrated indomethacin increased with the increasing of the concentration of PKO used in the formulation. This finding can be explained by the fact that PKO is an oily material that can occlude the stratum corneum so preventing transepidermal water loss. Thus, the water contains of the stratum corneum will increase. Hydration of the skin appears to increase the penetration of both hydrophilic and lipophilic permeants [5].

Effect of PKO hydrolyzed product concentration on the in vitro indomethacin penetration through rabbit skin

Fig. 5 shows the effect of hydrolyzed product on the penetration of indomethacin in vitro. The results show that the amount of penetrated indomethacin increased with the increasing of the concentration of PKO hydrolyzed product used in the formulation. The amount of penetrated indomethacin through rabbit skin to the medium in the receptor

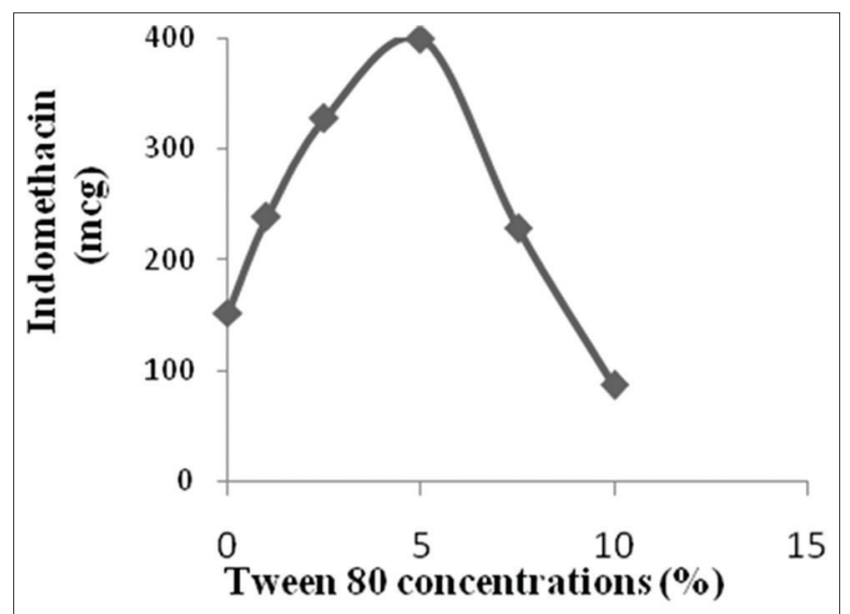

Fig. 3: Effect of Tween 80 at various concentration on the in vitro penetration of indomethacin in $\mathrm{pH} 7.4$ of phosphate buffer solution at $37^{\circ} \mathrm{C}$

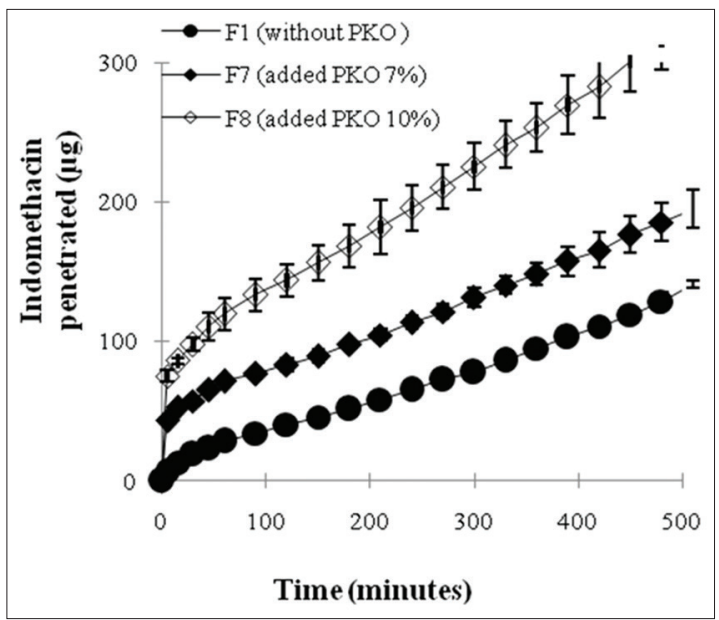

Fig. 4: Effect of palm kernel oil concentration on the in vitro penetration of indomethacin in $\mathrm{pH} 7.4$ of phosphate buffer solution at $37^{\circ} \mathrm{C}$ compartment was higher in the formula contained hydrolyzed product compared to formula without hydrolyzed product.

The amount of penetrated indomethacin increased with the increasing concentration of PKO hydrolyzed product used in the formulation. This finding can be explained by the fact that PKO hydrolyzed product which containing various free fatty acid, there are lauric acid (48.2\%), myristic acid (16.2\%), palmitic acid (8.4\%), capric acid (3.4\%), caprylic acid (3.3\%), stearic acid (2.5\%), oleic acid (15.3\%), and linoleic acid $(2.3 \%)$ [8]. Fatty acid increases the penetration by disrupting the lipid of stratum corneum so that increase the lipid fluidity within the stratum corneum [15]. Furthermore, fatty acid and its analogs enhancing effect may be due to they can form lipophilic complexes with drugs [16].

Effect of PKO transesterificated product concentration on the in vitro indomethacin penetration through rabbit skin

Fig. 6 shows the effect of transesterificated product on the penetration of indomethacin in vitro. The results show that the amount of penetrated indomethacin increased with the increased of the concentration of PKO transesterificated product used in the formulation. The amount of penetrated indomethacin through rabbit skin to the medium in the receptor compartment was higher in the formula contained transesterificated product compared to formula without transesterificated product.

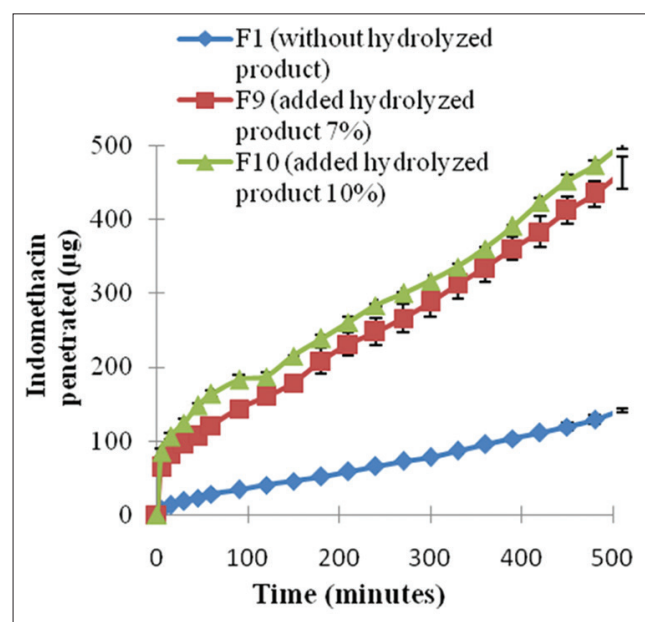

Fig. 5: Effect of palm kernel oil hydrolyzed product at concentration of $7 \%$ on the in vitro penetration of indomethacin in $\mathrm{pH} 7.4$ of phosphate buffer solution at $37^{\circ} \mathrm{C}$

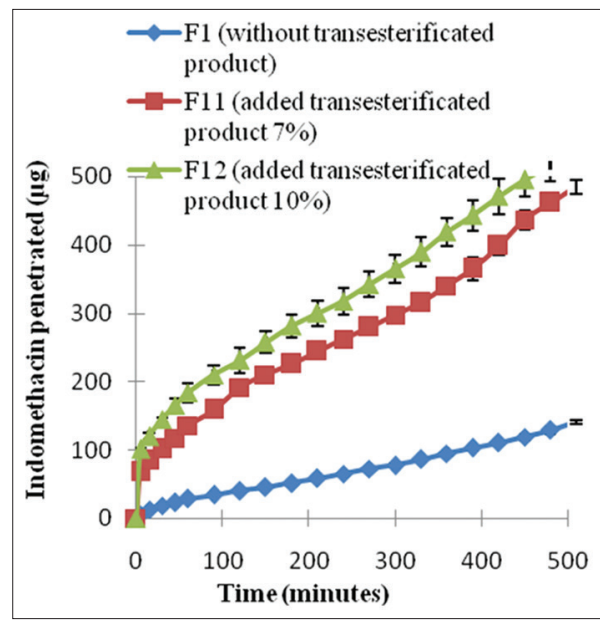

Fig. 6: Effect of palm kernel oil transesterificated product on the in vitro penetration of indomethacin in $\mathrm{pH} 7.4$ of phosphate buffer solution at $37^{\circ} \mathrm{C}$ 
Table 1: Compositions of each formulation

\begin{tabular}{|c|c|c|c|c|c|c|c|c|c|c|c|c|c|}
\hline \multirow[t]{2}{*}{ Composition (\%) } & \multicolumn{13}{|c|}{ Formulations } \\
\hline & F1 & F2 & F3 & F4 & F5 & F6 & F7 & F8 & F9 & F10 & F11 & F12 & F13 \\
\hline Indomethacin & 1 & 1 & 1 & 1 & 1 & 1 & 1 & 1 & 1 & 1 & 1 & 1 & 1 \\
\hline Tween 80 & & 1 & 2.5 & 5 & 7.5 & 10 & & & & & & & 5 \\
\hline PKO & & & & & & & 7 & 10 & & & & & \\
\hline Hydrolyzed PKO & & & & & & & & & 7 & 10 & & & \\
\hline Transesterifica-ted PKO & & & & & & & & & & & 7 & 10 & 10 \\
\hline White petrolatum & 99 & 98 & 96.5 & 94 & 91.5 & 89 & 92 & 89 & 92 & 89 & 92 & 89 & 84 \\
\hline
\end{tabular}

PKO: Palm kernel oil

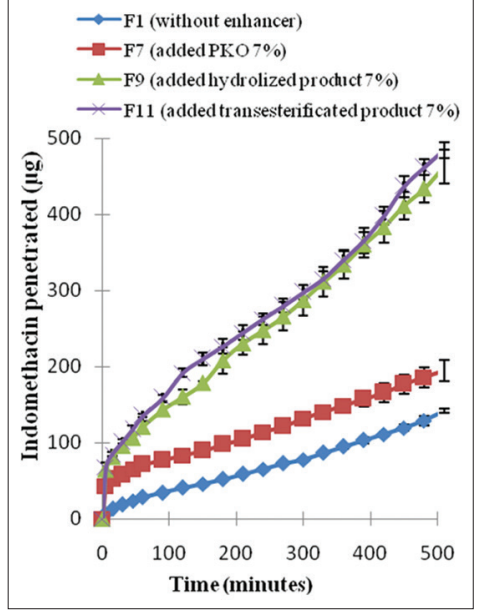

Fig. 7: Effect of palm kernel oil, palm kernel oil hydrolyzed product and palm kernel oil transesterificated product at concentration of $7 \%$ on the in vitro penetration of indomethacin in $\mathrm{pH} 7.4$ of phosphate buffer solution at $37^{\circ} \mathrm{C}$

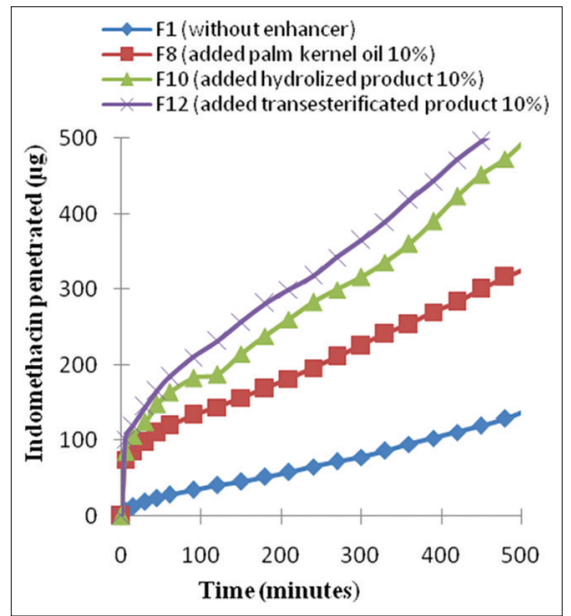

Fig. 8: Effect of palm kernel oil, palm kernel oil hydrolyzed product and palm kernel oil transesterificated product at concentration of $10 \%$ on the in vitro penetration of indomethacin in $\mathrm{pH} 7.4$ of phosphate buffer solution at $37^{\circ} \mathrm{C}$

The amount of penetrated indomethacin increased with the increasing of the concentration of PKO transesterificated product used in the formulation. The penetration enhancing effect of PKO transesterificated product which containing various fatty acid methyl ester was expected almost the same as PKO hydrolyzed product which containing various fatty acid. That is because of fatty acid methyl ester is a fatty acid analog, but fatty acid methyl ester is more nonpolar than fatty acid. Both of them increased the penetration by disrupting the lipid of stratum corneum so that increased the lipid fluidity within the stratum corneum [15,17].

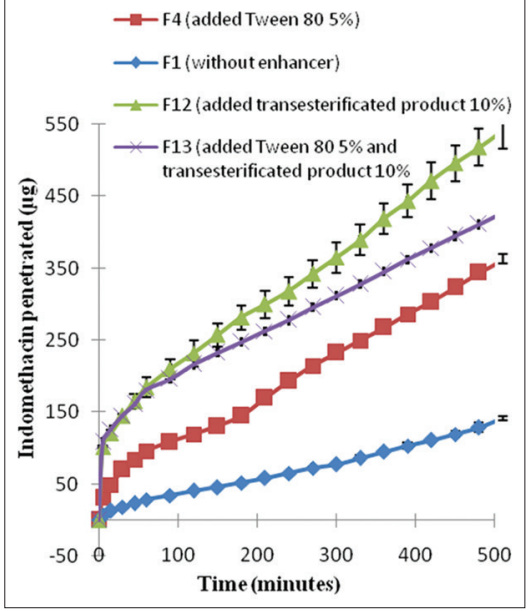

Fig. 9: Effect of combination of 5\% Tween 80 with $10 \%$ palm kernel oil transesterificated product on the in vitro penetration of indomethacin in $\mathrm{pH} 7.4$ of phosphate buffer solution at $37^{\circ} \mathrm{C}$

Comparison of the effect of PKO and its conversion product on the in vitro indomethacin penetration through rabbit skin

Fig. 7 shows the comparison of the effect of PKO, PKO hydrolyzed product and PKO transesterificated product at concentration of $7 \%$ on the penetration of indomethacin in vitro and in Fig. 8 at the concentration $10 \%$. The result shows the amount of penetrated indomethacin through rabbit skin to the medium in the receptor compartment was higher in the formula contained conversion product. Hydrolyzed product showed the significantly higher indomethacin penetration enhancement effect than PKO, while transesterificated product shows the significantly higher penetration enhancement effect compared to hydrolyzed product.

Effect of combination of Tween 80 with PKO transesterificated product on the in vitro indomethacin penetration through rabbit skin

Fig. 9 shows the combination effect of Tween 80 with PKO transesterificated product. The result shows that combination of $5 \%$ Tween 80 as the optimum concentration with $10 \%$ PKO transesterificated product as the best PKO conversion product shows the lower penetration enhancing effect compared to $10 \%$ PKO transesterificated product only, but the combination showed higher penetration enhancing effect compared to $5 \%$ Tween 80 only. This result suggests that there is an interaction between Tween 80 with PKO transesterificated product.

\section{CONCLUSION}

This work shows that Tween 80 at low concentration (1\%, 2.5\%, and $5 \%$ ) could enhance indomethacin penetration. The higher of the concentration of Tween 80, the higher of the indomethacin penetration. However, at high concentration $(7.5 \%$ and $10 \%)$, it decreases indomethacin penetration with the increase concentration of Tween 80 
used. PKO and its conversion products could enhance indomethacin penetration. The amount of indomethacin penetrated increases with the increase of the concentration of PKO and its conversion products used. Hydrolyzed product has higher indomethacin penetration effect than PKO. Transesterificated product has the highest penetration effect. However, the combination of Tween 80 with transesterificated product has lower penetration enhancing effect compared to transesterificated product only.

\section{REFERENCES}

1. Insel PA. Analgetics-antipyretics and anti-inflamatory agents: Drugs employed in the treatment of rheumatoid arthritis and gout. In: Gilman AG, Rall TW, Nies AS, Taylor P, editors. The Pharmacological Basic of Therapeutics. $8^{\text {th }}$ ed. New York: Pergamon Press; 1990. p. 639-81.

2. Trommer H, Neubert RH. Overcoming the stratum corneum: The modulation of skin penetration. A review. Skin Pharmacol Physiol 2006;19(2):106-21.

3. Moffat AC, Osselton MD, Widdop B. Clarke's Analysis of Drugs and Poisons. London: Pharmaceutical Press; 2005. p. 366-9.

4. Barry BW. Dermatological Formulation: Percutaneous Absorption. New York: Marcel Dekker, Inc.; 1983. p. 8-13.

5. Williams AC, Barry BW. Penetration enhancers. Adv Drug Deliv Rev 2004;56:603-18.

6. Jona JA, Dittert LW, Crooks PA, Milosovich SM, Hussain AA. Design of novel prodrugs for the enhancement of the transdermal penetration of indomethacin. Int J Pharm 1995;123(1):127-36.

7. Prakash PR, Rao NG, Soujanya C. Formulation, evaluation and anti- inflamatory activity of topical etoricoxib gel. Asian J Pharm Clin Res 2010;3(2):126-9.

8. Alamu OJ, Waheed MA, Jekayinfa SO. Effect of ethanol palm kernel oil ratio on alkali-catalyzed biodiesel yield. Fuel 2008;87(8-9):1529-33.

9. Shinde M, Gharge V, Pimple S, Gurjar M, Shah M. Effect of penetration enhancer on the in vitro ex vivo permeation of diclofenac gel. Asian J Pharm Clin Res 2014;7(5):255-9.

10. Akhtar N, Rehman MU, Khan HM, Rasool F, Saeed T, Murtaza G. Penetration enhancing effect of polysorbate 20 and 80 on the in vitro percutaneous absorption of L-ascorbic acid. Trop J Pharm Res 2011;10(3):281-8.

11. Agus D, Anayanti A, Hakim B. Study of the effects of tween 80 and palm kernel oil on in vitro ascorbic acid penetration through rabbit skin. Int J PharmTech Res 2013;5(3):965-72.

12. Patel KN, Patel HK, Patel VA. Formulation and characterization of drug in adhesive transdermal patches of diclofenac acid. Int J Pharm Pharm Sci 2012;4(1):26-34.

13. Denge MS, Walde SR, Ittadwar AM. Development and characterization of transdermal patches of ondansetron hydrochloride. Int J Pharm Pharm Sci 2012;4 Suppl 5:293-8.

14. Patrick JS, Yashveer S. Martin's Physical Pharmacy and Pharmaceutical Sciences. $6^{\text {th }}$ ed. Baltimore, MD: Lippincott Williams \& Wilkins; 2011. p. 389-90.

15. Golden GM, McKie JE, Potts RO. Role of stratum corneum lipid fluidity in transdermal drug flux. J Pharm Sci 1987;76(1):25-8.

16. Komata Y, Kaneko A, Fujie T. Effect of fatty acid on the accumulation of thiamine disulfide in rat skin. Biol Pharm Bull 1994;17(5):705-8.

17. David F, Paul C, Jorge H. Simple alkyl esters as skin permeation enhancers. J Control Release 1989;9(1):33-41. 